\title{
A mouse model for Costello syndrome reveals an Ang II-mediated hypertensive condition
}

\author{
Alberto J. Schuhmacher, ${ }^{1}$ Carmen Guerra, ${ }^{1}$ Vincent Sauzeau, ${ }^{2}$ \\ Marta Cañamero, ${ }^{3}$ Xosé R. Bustelo, ${ }^{2}$ and Mariano Barbacid1 \\ ${ }^{1}$ Molecular Oncology Programme, Centro Nacional de Investigaciones Oncológicas, Madrid, Spain. \\ ${ }^{2}$ Centro de Investigación del Cáncer, CSIC/University of Salamanca, Campus Unamuno, Salamanca, Spain. \\ ${ }^{3}$ Biotechnology Programme, Centro Nacional de Investigaciones Oncológicas, Madrid, Spain.
}

\begin{abstract}
Germline activation of $\mathrm{H}-\mathrm{RAS}$ oncogenes is the primary cause of Costello syndrome (CS), a neuro-cardio-faciocutaneous developmental syndrome. Here we describe the generation of a mouse model of CS by introduction of an oncogenic Gly12Val mutation in the mouse H-Ras locus using homologous recombination in ES cells. Germline expression of the endogenous $\mathrm{H}-\mathrm{R}^{\mathrm{G}}{ }^{\mathrm{G} 12 \mathrm{~V}}$ oncogene, even in homozygosis, resulted in hyperplasia of the mammary gland. However, development of tumors in these mice was rare. H-Ras ${ }^{\mathrm{G} 12 \mathrm{~V}}$ mutant mice closely phenocopied some of the abnormalities observed in patients with CS, including facial dysmorphia and cardiomyopathies. These mice also displayed alterations in the homeostasis of the cardiovascular system, including development of systemic hypertension, extensive vascular remodeling, and fibrosis in both the heart and the kidneys. This phenotype was age dependent and was a consequence of the abnormal upregulation of the renin-Ang II system. Treatment with captopril, an inhibitor of Ang II biosynthesis, prevented development of the hypertension condition, vascular remodeling, and heart and kidney fibrosis. In addition, it partially alleviated the observed cardiomyopathies. These mice should help in elucidating the etiology of CS symptoms, identifying additional defects, and evaluating potential therapeutic strategies.
\end{abstract}

\section{Introduction}

Costello syndrome (CS) $(1,2)$ belongs to a group of neuro-cardiofacio-cutaneous (NCFC) developmental syndromes that include Noonan syndrome (NS), cardio-facio-cutaneous (CFC) syndrome, and LEOPARD syndrome (LS) as well as familial type 1 neurofibromatosis (NF1) $(3,4)$. Recently, it has been observed that NCFC syndromes result from de novo germline mutations that alter the RAS/RAF/MEK signaling pathway $(3,4)$. Although there is significant overlap in their clinical manifestations, each syndrome is characterized by mutations in specific loci. Most CS patients carry mutations in $\mathrm{H}-\mathrm{RAS}(5-8)$, although some CS patients sharing features with NS and CFC syndrome have been shown to carry mutations in the K-RAS locus (9-12). About half of NS patients have mutations in PTPN11 (13). Mutations in other loci, including SOS1, K-RAS, and RAF1, account for about $25 \%$ of cases (14-19). Most patients with CFC syndrome harbor mutations in B-RAF, although other genes of the RAS/RAF/MEK pathway, mainly those encoding MEK1 and MEK2 as well as K-RAS, have also been identified $(20,21)$. Germline PTPN11 mutations cause $90 \%$ of LS cases $(22,23)$. Recently, it has been shown that some LS patients harboring a normal PTPN11 locus carry RAF1 mutations (17). Finally, all NF1 patients display inactivating mutations in NF1, a locus that encodes neurofibromin, a RAS GAP protein (24-26).

The RAS/RAF/MEK signaling pathway plays a central role in the regulation of many cellular responses, including metabolism,

Nonstandard abbreviations used: ACE, Ang II converting enzyme; CFC, cardiofacio-cutaneous; CS, Costello syndrome; DMBA, 7,12-dimethylbenz(a)anthracene; ET, endothelin; $\beta$-geo, $\beta$-gal-neomycin resistance fusion protein; IRES, internal ribosomal entry site; NCFC, neuro-cardio-facio-cutaneous; NF1, familial type 1 neurofibromatosis; NS, Noonan syndrome; SNS, sympathetic nervous system; TPA, 12-O-tetradecanoylphorbol-13-acetate.

Conflict of interest: The authors have declared that no conflict of interest exists. Citation for this article: J. Clin. Invest. 118:2169-2179 (2008). doi:10.1172/JCI34385 cell proliferation and differentiation, and apoptosis. Thus, it is not surprising that malfunction of this pathway during embryogenesis and postnatal development results in the multiple clinical manifestations associated with NCFC syndromes, such as developmental delay, cardiomyopathies, musculoskeletal abnormalities, mental retardation, and other physiological and neurological defects. Moreover, most of these loci are also mutated in human cancers (3). Yet NCFC mutations in K-RAS, B-RAF, and PTPN11 loci are distinct from those in somatic tumors and consistently result in milder activation of their gene products $(3,4)$. H-RAS appears to be an exception. Although some mild activating mutations have been recently identified (27), about $80 \%$ of CS patients carry $\mathrm{H}-\mathrm{RAS}$ alleles harboring mutations previously identified in human tumors (refs. 5-8 and the COSMIC database; http://www. sanger.ac.uk/genetics/CGP/cosmic).

To better understand the developmental and physiological defects associated with CS and their interplay with neoplastic development, we generated a strain of genetically modified mice carrying a germline $\mathrm{G} 12 \mathrm{~V}$ mutation within their endogenous H-Ras locus. These mice were viable, had a very low incidence of tumors, and displayed many of the phenotypic abnormalities observed in CS patients $(1,2)$. We also found that these mutant mice developed a renin-Ang II-dependent hypertensive condition, a phenotype that could be prevented by subjecting H-Ras ${ }^{\mathrm{G} 12 \mathrm{~V}}$ mutant animals to standard antihypertensive treatments. These mice offer a relevant experimental tool to study the alterations underlying the clinical manifestations of CS and to test new therapies aimed at preventing or ameliorating these deficits.

\section{Results}

Generation of H-Ras mutant mice. To generate a mouse model for $\mathrm{CS}$, we targeted ES cells by knocking in an oncogenic $\mathrm{G} \rightarrow \mathrm{T}$ missense mutation in the second base of the twelfth codon 
A

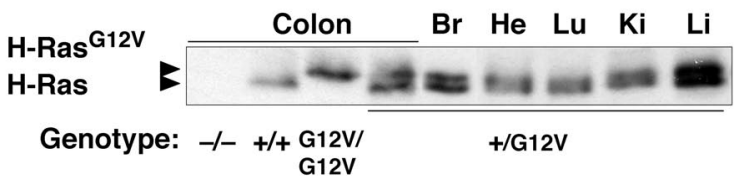

B

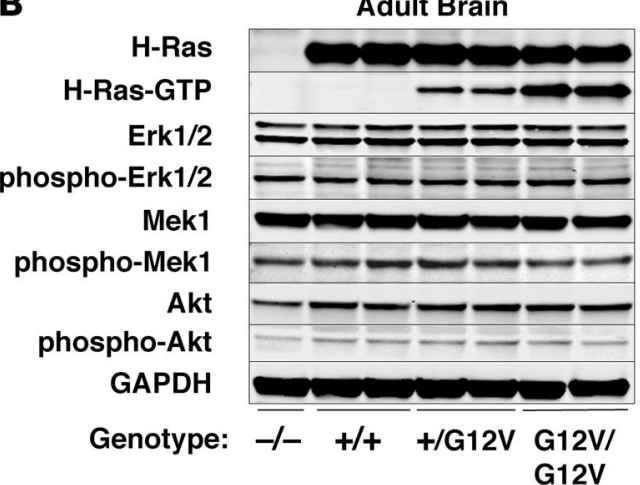

E14.5 Embryos

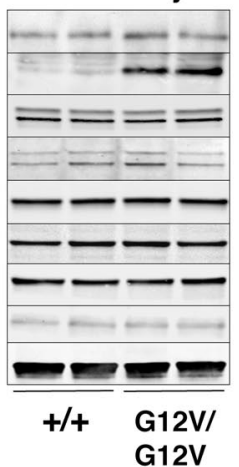

Figure 1

Functional characterization of the $\mathrm{H}$-Ras signaling pathway in $\mathrm{H}$-Ras ${ }^{\mathrm{G} 12 \mathrm{~V}}$ adult brain and E14.5 embryos. (A) Western blot analysis of the expression levels of wild-type $\mathrm{H}-\mathrm{Ras}^{+/+}$and mutant $\mathrm{H}-\mathrm{Ras}^{\mathrm{G} 12 \mathrm{~V}}$ proteins. Protein extracts $(200 \mu \mathrm{g})$ derived

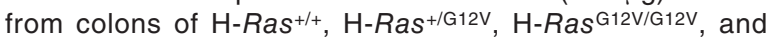
$\mathrm{H}-\mathrm{Ras}^{-1-}$ mice as well as from brain $(\mathrm{Br})$, heart $(\mathrm{He})$, lung $(\mathrm{Lu})$, kidney (Ki), and liver ( $\mathrm{Li})$ of $\mathrm{H}-\mathrm{Ras}^{+/ \mathrm{G} 12 \mathrm{~V}}$ animals were subjected to Western blot analysis. In the case of brain, only one-fourth of the sample was loaded. Migration of the wild-type H-Ras and mutant $\mathrm{H}$-Ras $\mathrm{G}^{\mathrm{G}} 2 \mathrm{~V}$ proteins is indicated by arrowheads. (B) Protein extracts $(40 \mu \mathrm{g})$ from the indicated genotypes obtained from 2-month-old adult brains and E14.5 whole embryos were resolved by SDS-PAGE, transferred to a nitrocellulose membrane, and blotted with antibodies against $\mathrm{H}$-Ras and the nonphosphorylated and phosphorylated forms of Erk1/2, Mek1, and Akt. Levels of active H-Ras protein bound to GTP (H-Ras-GTP) were determined by its ability to interact with the Ras binding domain of c-Raf. GAPDH was used as loading control. of the H-Ras locus (Supplemental Figure 1; supplemental material available online with this article; doi:10.1172/ JCI34385DS1). This strategy allowed the replacement of the normal GGA sequence (Gly) with GTA (Val), a mutation detected in a number of CS patients that leads to expression of a constitutively active $\mathrm{H}-\mathrm{Ras}^{\mathrm{G} 12 \mathrm{~V}}$ protein (5). To monitor $\mathrm{H}$-Ras expression at the single-cell level, we also inserted within the $3^{\prime}$ untranslated sequences of the H-Ras gene an internal ribosomal entry site- $\beta$-gal-neomycin resistance fusion protein (IRES- $\beta$-geo) cassette (Supplemental Figure 1). These extra sequences allowed the expression of a chimeric protein with $\beta$-gal activity under the regulation of the endogenous $\mathrm{H}$-Ras proto-oncogene promoter, thereby enabling histological detection of gene expression patterns using X-gal staining methods (28). These mutant mice, designated as $\mathrm{H}-\mathrm{Ras}^{+} / \mathrm{G} 12 \mathrm{~V}$, were born at the expected Mendelian ratio, were fertile, and survived at rates comparable to those of their wild-type counterparts for more than a year. Similar results were observed with homozygous H-Ras ${ }^{\mathrm{G} 12 \mathrm{~V} / \mathrm{G} 12 \mathrm{~V}}$ animals. H-Ras ${ }^{+} /$geo and $\mathrm{H}$-Ras $\mathrm{geo} / \mathrm{geo}$ mice expressing the $\beta$-geo protein from a nonmutated
H-Ras allele were also normal (data not shown). Western blot analysis showed that the levels of expression of the oncogenic $\mathrm{H}-\mathrm{Ras}^{\mathrm{G} 12 \mathrm{~V}}$ protein were similar to those of the endogenous wildtype H-Ras protein (Figure 1A), which indicates that the presence of the IRES- $\beta$-geo cassette does not affect expression of the targeted $\mathrm{H}-$ Ras $^{\mathrm{G} 12 \mathrm{~V}}$ locus.

Pattern of expression. Previous studies have shown that H-Ras is expressed in most - if not all - tissues (29). Yet analysis of H-Ras expression at the single-cell level in $\mathrm{H}$-Ras geo mice revealed a wide, but not ubiquitous, pattern of expression (Supplemental Figures 2-5). Sagittal sections of H-Ras ${ }^{\text {geo/geo }}$ midgestation embryos (E14.5) indicated that $\mathrm{H}$-Ras was expressed in most embryonic tissues. However, the different levels of $\beta$-gal activity in the various tissues suggests that the levels of $\mathrm{H}$-Ras expression are not uniform (Supplemental Figure 2). Adult mice displayed a selective pattern of expression. In the heart, we observed X-gal staining in cardiomyocytes, endothelial cells of the endocardium (Supplemental Figure 3A), and aortic vascular smooth muscle cells (Supplemental Figure 3B), but not in skeletal muscle (Supplemental
A

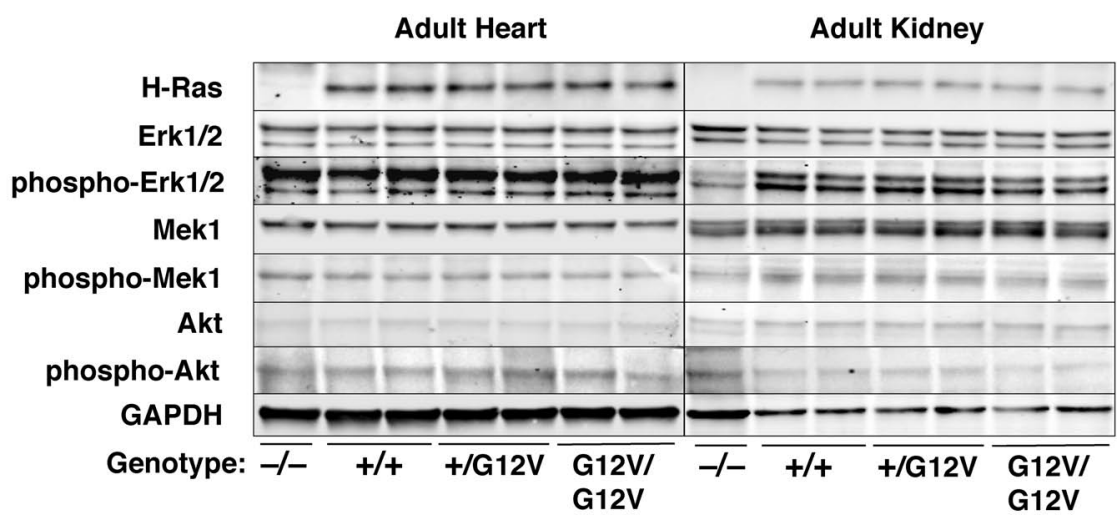

B Neonatal Heart Cardiom. Fibrobl.

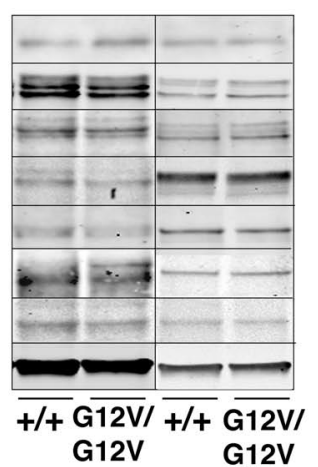

Figure 2

$\mathrm{H}$-Ras signaling in heart and kidneys of H-Ras $\mathrm{G}_{12 \mathrm{~V}}$ mutant mice. Protein extracts (40 $\left.\mu \mathrm{g}\right)$ obtained from (A) heart and kidneys of 2-month-old $\mathrm{H}-\mathrm{Ras}^{-/-}, \mathrm{H}-\mathrm{Ras}^{+/+}, \mathrm{H}-\mathrm{Ras}^{+/ \mathrm{G} 12 \mathrm{~V}}$, and H-Ras G12V/G12V mice and from (B) cardiomyocytes and fibroblasts isolated form neonatal hearts of $\mathrm{H}-\mathrm{Ras}^{+/+}$ and $\mathrm{H}-$ Ras $^{\mathrm{G} 12 \mathrm{~V} / \mathrm{G} 12 \mathrm{~V}}$ animals were resolved by SDS-PAGE, transferred to nitrocellulose membranes, and blotted with antibodies against $\mathrm{H}$-Ras and the nonphosphorylated and phosphorylated forms of Erk1/2, Mek1, and Akt. GAPDH was used as loading control. 


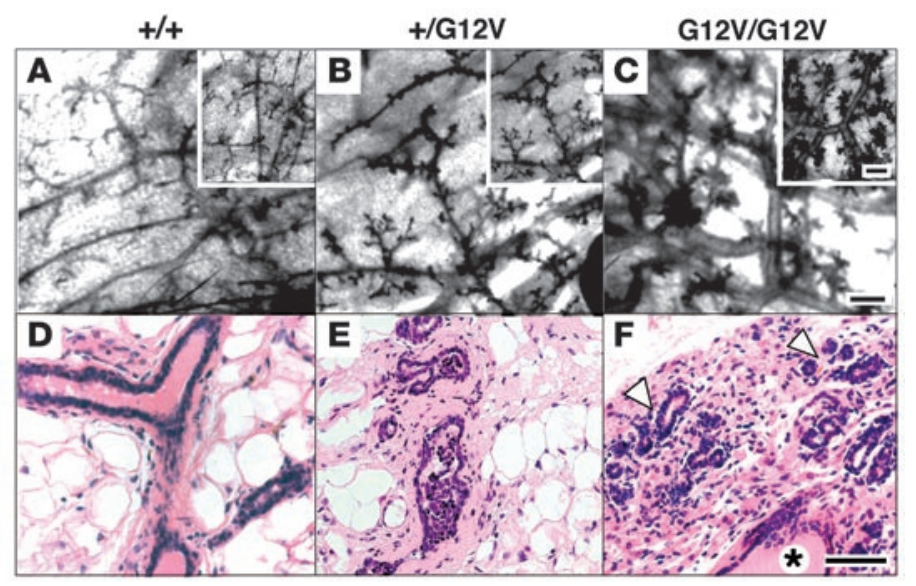

\section{Figure 3}

Mammary gland hyperplasia in $\mathrm{H}-\mathrm{Ras}^{\mathrm{G} 12 \mathrm{~V}}$ virgin female mice. Red carmine whole-mount staining $(\mathbf{A}-\mathbf{C})$ and $\mathrm{H} \& \mathrm{E}$ staining of paraffin sections (D-F) of mammary glands of $\mathrm{H}-\mathrm{Ras}^{+/+}(\mathbf{A}$ and $\mathbf{D})$, $\mathrm{H}-$ Ras $^{+/ \mathrm{G} 12 \mathrm{~V}}$ (B and E), and H-Ras G12V/G12V (C and F) mice. Insets show representative detail. Mammary glands of $\mathrm{H}-$ Ras $^{\mathrm{G} 12 \mathrm{~V} / \mathrm{G} 12 \mathrm{~V}}$ mice displayed substantial white fat atrophy, greater ductal-lobulillar development (arrowheads), and ductal ectasia (asterisk). Scale bars: $1 \mathrm{~mm}(\mathbf{A}-\mathbf{C}) ; 10 \mu \mathrm{m}(\mathbf{D}-\mathbf{F})$.
Figure 3C). In the kidney, all histological structures displayed $\mathrm{X}$-gal staining (Supplemental Figure 4A). In the mammary glands, $\mathrm{X}$-gal staining was observed in myoepithelial ductal and alveolar cells, but not in luminal epithelial cells (Supplemental Figure 4B). Likewise, all layers of the skin epithelium, sebaceous glands, and hair follicles displayed $\beta$-gal activity (Supplemental Figure 4C). The urinary bladder displayed robust X-gal staining levels in both epithelial mucosa and muscular cell layers (Supplemental Figure 4D). In the pancreas, X-gal staining was observed in endocrine islets but not in the exocrine pancreas (Supplemental Figure 4E). The colon showed uniform X-gal staining, suggesting an ubiquitous pattern of H-Ras expression (Supplemental Figure 4F). Most brain structures, including hippocampus and cortex, also displayed robust $\beta$-gal activity (Supplemental Figure 4, G and $\mathrm{H}$ ). Only the cerebellum displayed low $\beta$-gal activity (data not shown). In the lung, Clara cells, identified by immunostaining with CC10 antibodies, also displayed robust X-gal staining (Supplemental Figure 5, A and B). However, a small fraction of type II pneumocytes, identified by immunostaining with SPC antibodies, displayed $\beta$-gal activity (Supplemental Figure 5, A and C). Whether this is due to low levels of $\mathrm{H}$-Ras expression in these cells remains to be determined. Finally, hematopoietic organs such as spleen and thymus displayed low levels of H-Ras expression (data not shown). Detailed comparison of the expression pattern of H-Ras ${ }^{\mathrm{G} 12 \mathrm{~V}}$, as determined by X-gal staining, in $\mathrm{H}-$ Ras $^{\mathrm{G} 12 \mathrm{~V}}$ mice revealed a similar pattern of expression (data not shown). Thus, suggesting that expression of the oncogenic H-Ras ${ }^{\mathrm{G} 12 \mathrm{~V}}$ protein does not perturb, at least significantly, the pattern of expression of the endogenous H-Ras locus.

Molecular analysis of H-Ras signaling pathways. The mutant H-Ras ${ }^{\mathrm{G} 12 \mathrm{~V}}$ protein was found bound to GTP, as determined by its ability to interact with the Ras-binding domain of c-Raf (Figure 1B). As expected, the amount of H-Ras ${ }^{\mathrm{G} 12 V_{-}}$GTP was twice as abundant in H-Ras ${ }^{\mathrm{G} 12 \mathrm{~V} / \mathrm{G} 12 \mathrm{~V}}$ mice
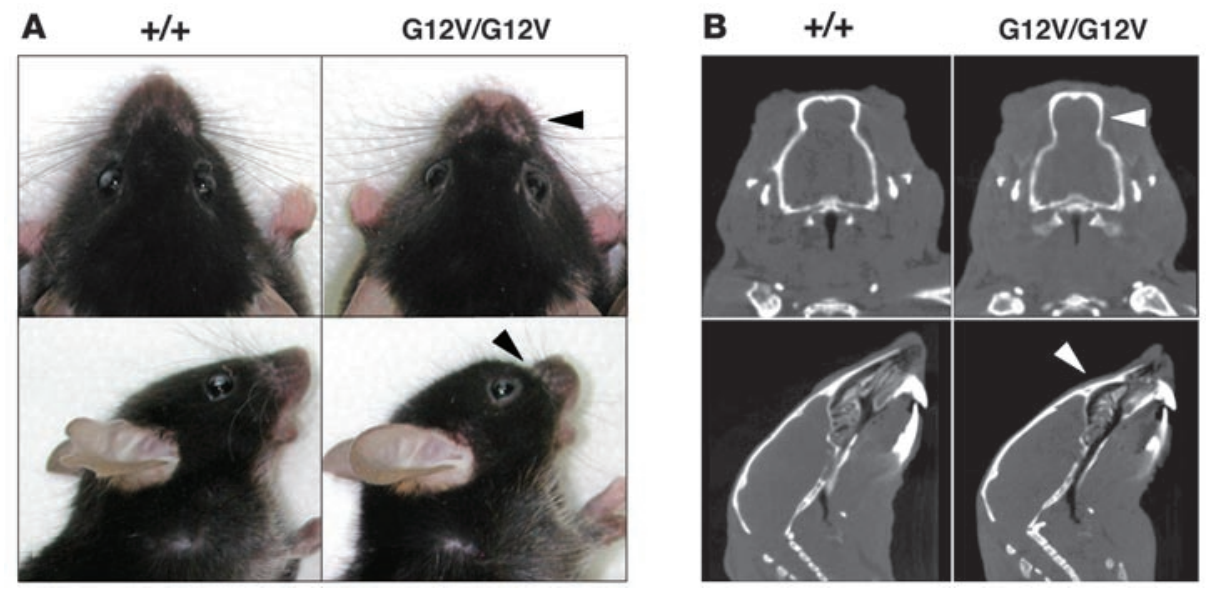

\section{Figure 4}

Facial dysmorphia. (A) Top and side views of heads of $\mathrm{H}-\mathrm{Ras}^{+/+}$and $\mathrm{H}-\mathrm{Ras}^{\mathrm{G} 12 \mathrm{~V} / \mathrm{G} 12 \mathrm{~V}}$ mice illustrating the prominent forehead and blunt nose of mutant animals (arrowheads). (B) CT sections of $\mathrm{H}-$ Ras $^{+/+}$and H-Ras G12V/G12V littermates. Top: Coronal projection. Arrowhead indicates choanal atresia. Bottom: Sagittal projection. Arrowhead indicates the shortened and depressed nasal bridge and premaxillar bone. 


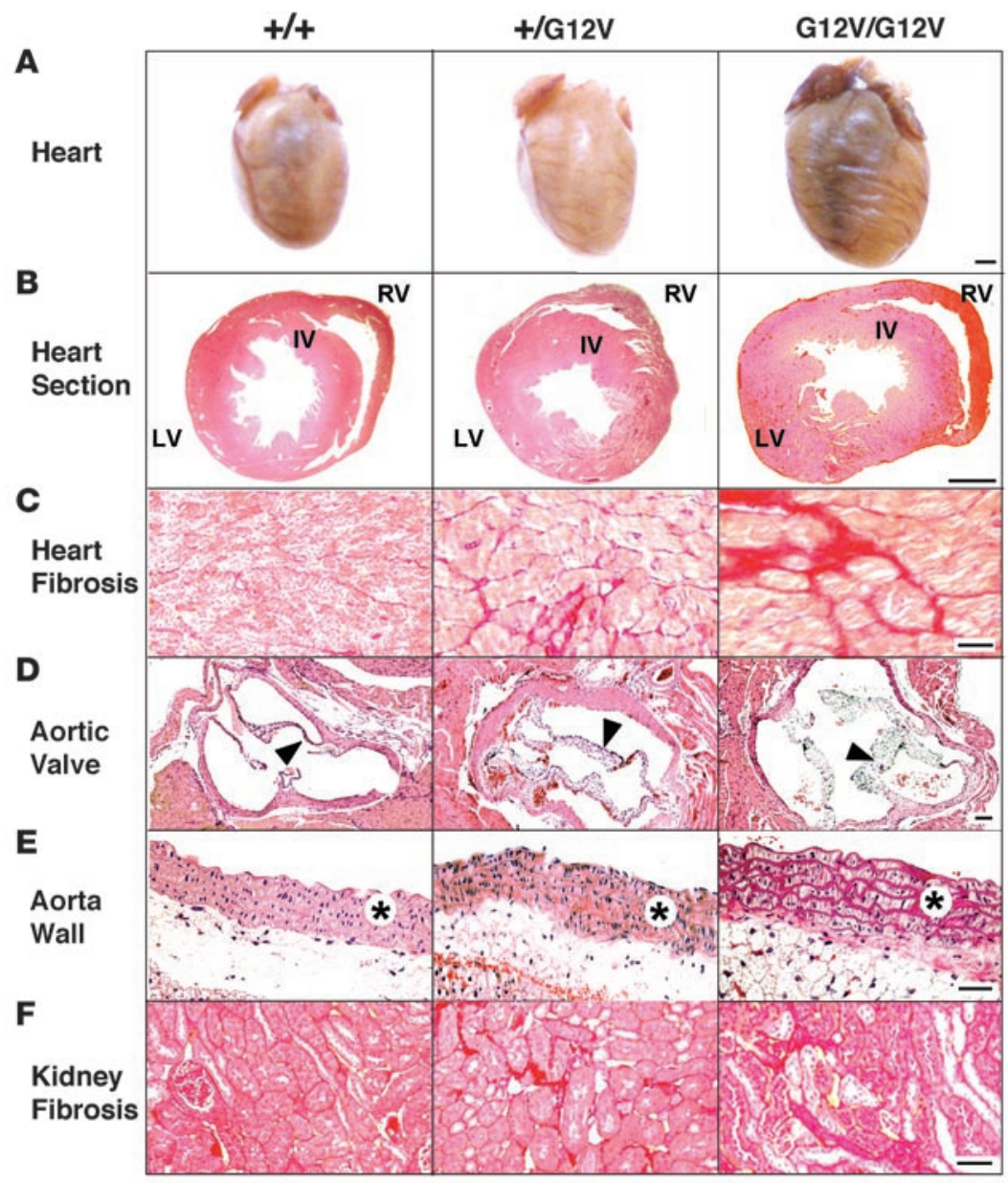

Figure 5

Heart and kidney defects in $\mathrm{H}-$ Ras $^{\mathrm{G} 12 \mathrm{~V}}$ mice. (A) Formalin-fixed hearts. (B) H\&E-stained heart ventricular sections. Interventricular wall (IV), LV, and RV are indicated. (C) Fibrosis in the LV, as shown by Sirius red-stained preparations. (D) H\&E-stained aortic valves (arrowheads). (E) H\&E-stained aorta media wall (asterisks). (F) Kidney fibrosis, as shown by Sirius red-stained preparations. Scale bars: $1 \mathrm{~mm}(\mathbf{A}$ and $\mathbf{B}) ; 50 \mu \mathrm{m}(\mathbf{D})$; $100 \mu \mathrm{m}(\mathbf{C}, \mathbf{E}$, and F).

H-Ras ${ }^{G 12 V}$ mice are not prone to tumor development. Although CS patients have certain predisposition to tumor development, tumors - primarily neuroblastomas, rhabdomyosarcomas, and bladder carcinomas - have been observed in about $10 \%$ of CS patients (30). Whether adult CS patients have a higher incidence of tumors is not known. Of the H-Ras ${ }^{\mathrm{G} 12 \mathrm{~V}}$ mutant mice, 19 of 20 remained tumor free for at least 1.5 years regardless of whether they carried the targeted allele in heterozygosity or homozygosity. Yet $\mathrm{H}-$ Ras $^{\mathrm{G} 12 \mathrm{~V}}$ virgin and multiparous females consistently developed hyperplasia in their mammary glands at approximately 4 months of age (Figure 3 ). This phenotype was characterized by higher ductal branching and alveolar proliferation, along with a slight decrease in adipose tissue. Greater ductal-lobulillar development and ductal ectasia, with mild periductal-alveolar fibrosis, was also observed (Figure 3). However, these mammary glands did not show atypia, increased mitotic index, or signs of squamous metaplasia in the epithelium (Figure 3, D-F). At 1.5 years of age, 1 of 9 female mice developed a mammary adenocarcinoma. This tumor displayed striking atypia, geographic necrosis, and a high mitotic index (Supplemental Figure 6). Immunostaining with cytokeratin 8 (Supplemental Figure 6), cytokeratin 14, and pankeratin AE1-AE3 markers (data not shown) illustrated its epithelial origin. Additional immunostaining revealed expression of estrogen receptor $\alpha$, progesterone receptor (data not shown), and focal detection of phosphorylated Erk (Supplemental Figure 6).

$H$-Ras ${ }^{G 12 V}$ is not sufficient to initiate skin carcinogenesis. H-Ras oncogenes have been implicated in the initiation of skin carcinogenesis induced by the classical 7,12-dimethylbenz(a)anthracene/12-Otetradecanoylphorbol-13-acetate (DMBA/TPA) protocol $(31,32)$. Because $\mathrm{H}-$ Ras $^{\mathrm{G} 12 \mathrm{~V}}$ mice already harbor an H-Ras oncogene in all their cells, we reasoned that treatment with the TPA tumor promoter should suffice to induce papilloma development. Topical administration of TPA to $\mathrm{H}$-Ras ${ }^{\mathrm{G} 12 \mathrm{~V}}$ mutant mice did not trigger papilloma development, but these mutant mice developed papillomas with the same incidence and latency as wild-type mice when submitted to DMBA/TPA treatment (Supplemental Figure 7). As expected, all papillomas obtained from DMBA/TPA-treated wild-type mice carried $\mathrm{H}$-Ras oncogenes activated by an $\mathrm{A} \rightarrow \mathrm{T}$ transversion in the middle base of codon 61 (33). This mutation was also observed in the wild-type allele of all papillomas resected from DMBA/TPA-treated H-Ras ${ }^{+/ G 12 V}$ mice $(n=7)$. However, this mutation was not observed in tumors obtained from H-Ras ${ }^{\mathrm{G} 12 \mathrm{~V} / \mathrm{G} 12 \mathrm{~V}}$ mice $(n=9)$. These observations indicate that H-Ras oncogenes contribute to papilloma development but are not sufficient to initiate the neoplastic process.

H-Ras ${ }^{G 12 V}$ mutant mice display facial dysmorphia. Both H-Ras ${ }^{+/ G 12 V}$ and H-Ras ${ }^{\text {G12V/G12V mice had }}$ normal size, weight, and proportioned overall dimensions. They also had normal cranium length and width as well as inner canthal distance (data not shown). However, they displayed facial dysmorphia, caused by depression of the anterior frontal bone, shortening and depression of the nasal bridge and premaxillar bone, and choanal atresia (Figure 4). They also showed shortened maxillary, molar process, and zygomatic bone (data not shown). Together, these defects induced a prominent forehead and blunt nose that clearly distinguished $\mathrm{H}-\mathrm{Ras}^{\mathrm{G} 12 \mathrm{~V}}$ mice from their wild-type littermates (Figure 4). These defects had a developmental origin, because they were observed in neonatal mice. Detailed analysis of neonatal mice by CT revealed significant differences in landmarks such as the anterior nasal area, nasal bone, center of alveolar ridge over maxillary incisor, and maxilla suture (Hotelling $T^{2}$ test; $n=15$; Supplemental Figure 8). $\mathrm{H}-\mathrm{Ras}^{\mathrm{G} 12 \mathrm{~V}}$ mutant mice also displayed engrossed lips, primarily as a result of the accumulation of adipocytes intersected between the skeletal muscle fascicles (Supplemental Figure 9, A and B). This accumulation effected distension of the vibrissal follicles, ultimately causing their rounded appearance. Moreover, the lip skin of $\mathrm{H}-\mathrm{Ras}^{\mathrm{G} 12 \mathrm{~V}}$ mice also showed more sebaceous glands than that of control animals. Finally, orcein staining revealed that 
Table 1

Cardiovascular parameters of 4-month-old wild-type and $\mathrm{H}$-Ras ${ }^{\mathrm{G} 12 \mathrm{~V}}$ mutant mice

\begin{tabular}{|c|c|c|c|}
\hline Parameter & H-Ras ${ }^{+/+}$ & $\begin{array}{l}\mathrm{H}-\text { Ras }^{+/ G 12 V} \\
\text { (\% change) }\end{array}$ & $\begin{array}{c}\text { H-Ras }{ }^{G 12 V / G 12 V} \\
\text { (\% change) }\end{array}$ \\
\hline Body weight (g) & $28.4 \pm 3.1$ & $27.6 \pm 2.9$ (NS) & $30.4 \pm 2.4$ (NS) \\
\hline Heart weight (mg) & $174.6 \pm 10.9$ & $212.8 \pm 16.6(21.9 \%)$ & $291.3 \pm 7.3(66.8 \%)$ \\
\hline Cardiomyocyte area, LV $\left(\mu \mathrm{m}^{2}\right)^{\mathrm{A}}$ & $213.3 \pm 7.7$ & $365.4 \pm 8.2(71.3 \%)$ & $492.2 \pm 12.5(130.8 \%)$ \\
\hline Cardiomyocyte area, $\mathrm{RV}\left(\mu \mathrm{m}^{2}\right)^{\mathrm{A}}$ & $378.0 \pm 28.5$ & $394.9 \pm 27.8$ (NS) & $395.5 \pm 26.4$ (NS) \\
\hline LV collagen content ( $\mu \mathrm{g} / \mathrm{mg}$ protein) & $11.4 \pm 0.8$ & $15.1 \pm 0.7(32.4 \%)$ & $18.1 \pm 1.6(58.8 \%)$ \\
\hline Aorta media wall thickness $(\mu \mathrm{m})$ & $42.1 \pm 6.1$ & $71.7 \pm 6.8(70.3 \%)$ & $69.1 \pm 5.2(64.1 \%)$ \\
\hline Systolic AP, conscious (mmHg) & $118.4 \pm 2.7$ & $144.8 \pm 5.9(22.3 \%)$ & $170.0 \pm 3.6(43.6 \%)$ \\
\hline Systolic AP, unconscious (mmHg) & $69.5 \pm 7.0$ & $87.3 \pm 5.5(25.6 \%)$ & $107.8 \pm 9.8(55.1 \%)$ \\
\hline Diastolic AP, unconscious (mmHg) & $43.6 \pm 2.6$ & $61.7 \pm 5.8(41.5 \%)$ & $82.4 \pm 4.0(88.9 \%)$ \\
\hline Mean AP, unconscious (mmHg & $53.5 \pm 0.5$ & $75.5 \pm 3.5(41.1 \%)$ & $95.0 \pm 6.3(77.6 \%)$ \\
\hline Heart rate, unconscious (bpm) & $553 \pm 28$ & $551 \pm 14(\mathrm{NS})$ & $569 \pm 16(\mathrm{NS})$ \\
\hline Heart rate, conscious (bpm) & $509 \pm 33$ & $524 \pm 14$ (NS) & $587 \pm 24(\mathrm{NS})$ \\
\hline Respiratory frequency (breaths/min) & $192 \pm 21$ & $205 \pm 20$ (NS) & $209 \pm 18$ (NS) \\
\hline Kidney collagen ( $\mu \mathrm{g} / \mathrm{mg}$ protein) & $18.3 \pm 2.6$ & $27.8 \pm 2.2(52.4 \%)$ & $35.7 \pm 3.0(95.1 \%)$ \\
\hline Creatinine clearance (ml/min) & $0.43 \pm 0.03$ & $0.19 \pm 0.01(-55.8 \%)$ & $0.21 \pm 0.02(-51.2 \%)$ \\
\hline Urine production $(\mu \mathrm{l} / \mathrm{d})$ & $1,262 \pm 94$ & $1,475 \pm 186(\mathrm{NS})$ & $1,310 \pm 83$ (NS) \\
\hline $\mathrm{Na}^{+}$excretion $(\mathrm{mEq} / \mathrm{d})$ & $0.16 \pm 0.03$ & $0.15 \pm 0.01$ (NS) & $0.14 \pm 0.01$ (NS) \\
\hline $\mathrm{K}^{+}$excretion $(\mathrm{mEq} / \mathrm{d})$ & $0.32 \pm 0.04$ & $0.34 \pm 0.02(\mathrm{NS})$ & $0.32 \pm 0.03$ (NS) \\
\hline $\mathrm{Cl}^{-}$excretion $(\mathrm{mEq} / \mathrm{d})$ & $0.47 \pm 0.03$ & $0.48 \pm 0.04$ (NS) & $0.51 \pm 0.05$ (NS) \\
\hline Norepinephrine (nmol/ml plasma) & $1.13 \pm 0.12$ & $1.60 \pm 0.21(41.6 \%)$ & $1.53 \pm 0.12(35.5 \%)$ \\
\hline Epinephrine (nmol/ml plasma) & $0.49 \pm 0.04$ & $0.63 \pm 0.06$ (NS) & $0.59 \pm 0.04(\mathrm{NS})$ \\
\hline
\end{tabular}

Values in parentheses denote percent change compared with wild-type. AP, arterial pressure. ${ }^{A}$ Cross-sectional area of cardiomyocytes in the indicated heart section; due to the internal architecture of LV and RV, values can be only compared among cardiomyocytes of the same ventricle. mutant lips had shorter elastic fibers that were also reduced in number (Supplemental Figure 9C).

$H$-Ras ${ }^{G 12 V}$ mutant mice develop cardiomyopathies. Because CS patients show a number of heart dysfunctions (34), we analyzed the cardiovascular system in adult $\mathrm{H}-$ Ras $^{\mathrm{G} 12 \mathrm{~V}}$ mice. We observed that 4-month-old H-Ras ${ }^{+/ G 12 V}$ mice displayed substantially larger heart chambers than wild-type mice (Figure 5, A and B, and Table 1). This enlargement was the result of independent events in different heart structures. The LV was enlarged because of concentric hypertrophy associated with increased cardiomyocyte size (Figure 5B and Table 1). Staining with Sirius red also showed elevated levels of interstitial collagen deposition, a sign of fibrosis (Figure 5C). The increase in collagen content was confirmed using independent biochemical assays (Table 1). We did not observe increased levels of chondroitin-bearing proteoglycans in hearts from animals bearing the $\mathrm{H}-\mathrm{Ras}^{\mathrm{G} 12 \mathrm{~V}}$ oncogene (data not shown), a defect previously found in some heart biopsies of dead CS patients (35). Enlargement of the auricles and RV was a consequence of an overall increase in the size of the wall and chambers without changes in either cell density or cell size (Table 1), implying an increase in the number of cardiomyocytes in these areas. Ki67 analysis failed to reveal significant differences between normal and mutant heart tissue, thus suggesting that the observed phenotype may result from a slight increase in the number of cardiac stem cells. Despite these alterations, electron microscopy analysis indicated that sarcomere organization was not altered in hearts expressing the $\mathrm{H}-\mathrm{Ras}^{\mathrm{G} 12 \mathrm{~V}}$ oncogene (Supplemental Figure 10).

$\mathrm{H}$-Ras ${ }^{\mathrm{G} 12 \mathrm{~V}}$ mutant mice also displayed enlarged aortic valves (Figure 5D), but normal pulmonary (Supplemental Figure
11) and atrioventricular valves (data not shown). This specificity is intriguing, because other mouse strains carrying an activated Ras pathway show defects in both aortic and pulmonary valves (36-38). Enlargement of the aortic valve was not due to differential expression levels of the targeted $\mathrm{H}-$ Ras $^{\mathrm{G} 12 \mathrm{~V}}$ allele, because we observed similar X-gal staining in all valves (Supplemental Figure 11). This cardiomyopathy was gene dose dependent: H-Ras ${ }^{\mathrm{G} 12 \mathrm{~V} / \mathrm{G} 12 \mathrm{~V}}$ mice displayed a more robust phenotype than $\mathrm{did} \mathrm{H}-\mathrm{Ras}^{+/ \mathrm{G} 12 \mathrm{~V}}$ mice (Figure 5 and Table 1). Some of these alterations were also time dependent: 6-week-old H-Ras ${ }^{\mathrm{G} 12 \mathrm{~V} / \mathrm{G} 12 \mathrm{~V}}$ mice had no signs of heart fibrosis, and their LV hypertrophy and aortic valve thickening was less pronounced than that of 4-month-old animals (data not shown). Real-time electrocardiogram analysis indicated that the heart hyperplasia of $\mathrm{H}-\mathrm{Ras}^{\mathrm{G} 12 \mathrm{~V} / \mathrm{G} 12 \mathrm{~V}}$ mice was not associated with significant heart arrhythmias (Supplemental Figure 12).

Ang II-dependent systemic hypertension in H-Ras ${ }^{G 12 V}$ mice. At 4 months of age, both H-Ras ${ }^{+\mathrm{G} 12 \mathrm{~V}}$ and, to a larger extent, H-Ras ${ }^{\mathrm{G} 12 \mathrm{~V} / \mathrm{G} 12 \mathrm{~V}}$ mice had developed systemic hypertension, characterized by high systolic and diastolic arterial pressures under anesthetized and conscious conditions (Table 1). As mice aged, they developed additional defects typically associated with systemic hypertension, including severe thickening and remodeling of aorta media walls, kidney fibrosis, and reduced excretion rates of creatinine by kidneys (Figure 5, E and F, and Table 1). Kidney fibrosis was associated with increased local production of TGF- $\beta$ (Supplemental Figure 13). High blood pressure was restricted to the systemic circulation, since we did not detect signs of pulmonary hypertension such as remodeling of pulmonary arterioles (data nor shown) or RV hypertrophy (Table 1 ).

To examine the origin of this hypertensive condition, we evaluated the kidneys and the sympathetic nervous system (SNS). Urine production and excretion rates of $\mathrm{Na}^{+}, \mathrm{K}^{+}$, and $\mathrm{Cl}^{-}$ions were not altered in $\mathrm{H}-$ Ras $^{\mathrm{G} 12 \mathrm{~V}}$ mice (Table 1), which suggests that hypertension is not caused by kidney dysfunction $(39,40)$. Likewise, plasma levels of norepinephrine and epinephrine, 2 catecholamines secreted by SNS neurons, were not significantly altered. We observed a moderate increase in the concentration of norepinephrine (Table 1 ), an expected result because slight activation of the SNS is typical of patients with high blood pressure $(39,41)$. Further analysis of these mutant mice revealed normal breathing activity and heartbeat frequencies, suggesting that the increased norepinephrine 

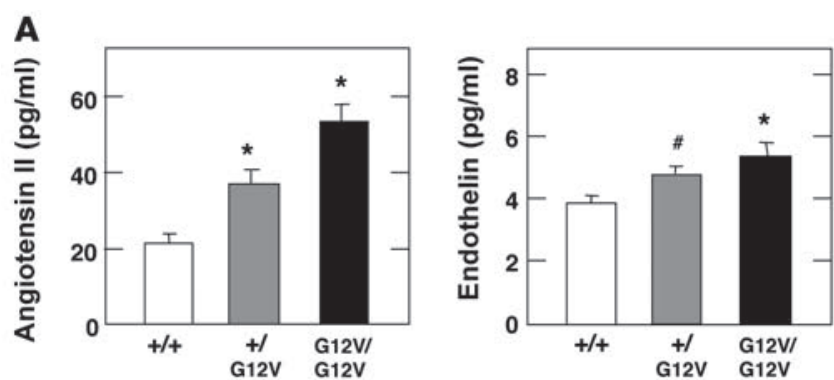

C

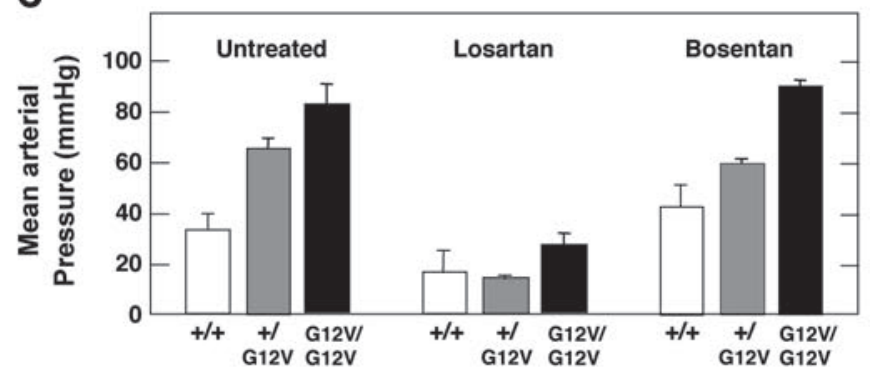

B

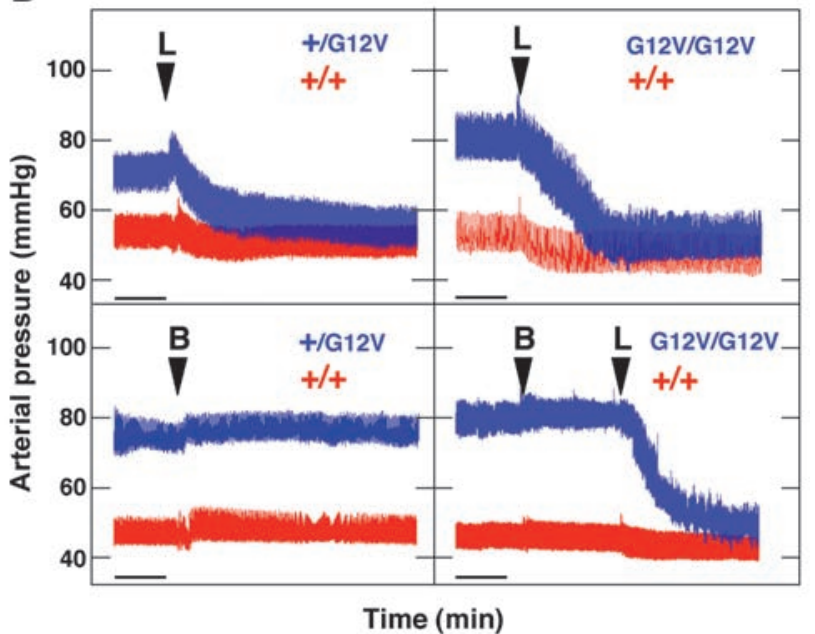

Figure 6

Analysis of the renin-Ang II and ET systems in H-Ras mutant mice. (A) Concentration of Ang II and ET in the plasma of mice of the indicated genotypes. ${ }^{*} P<0.01$, ${ }^{\#} P<0.05$ versus wild-type. (B) Representative real-time recordings of arterial blood pressure variations upon administration of bosentan (B) and/or losartan (L). Scale bar: $1 \mathrm{~min}$. (C) Quantification of mean arterial pressure upon administration of either bosentan or losartan. Values were taken when the arterial pressure became stabilized after the indicated treatment.

concentrations and high blood pressure were not caused by chronic stimulation of the SNS (41).

Next, we determined the levels of endothelin (ET) and Ang II, 2 peptide families frequently involved in hypertension $(39,42$, 43). As illustrated in Figure 6A, ET levels moderately increased in $\mathrm{H}-\mathrm{Ras}^{\mathrm{G} 12 \mathrm{~V} / \mathrm{G} 12 \mathrm{~V}}$ mice. However, Ang II levels were significantly elevated in $\mathrm{H}-\mathrm{Ras}^{\mathrm{G} 12 \mathrm{~V}}$ animals, especially in the H-Ras ${ }^{\mathrm{G} 12 \mathrm{~V} / \mathrm{G} 12 \mathrm{~V}}$ mice, whose Ang II levels were 2.5-fold that of wild-type animals (Figure 6A). To assess whether the increased levels of these vasoconstrictors were responsible for the hypertensive phenotype of $\mathrm{H}-\mathrm{Ras}^{\mathrm{G} 12 \mathrm{~V}}$ mice, we treated these animals with bosentan and losartan, specific inhibitors of ET and Ang II receptors, respectively. Injection of bosentan had no effect on blood pressure in either $\mathrm{H}-\mathrm{Ras}^{+} / \mathrm{G} 12 \mathrm{~V}$ or H-Ras ${ }^{\mathrm{G} 12 \mathrm{~V} / \mathrm{G} 12 \mathrm{~V}}$ mice (Figure 6, B and C). In contrast, treatment with losartan promoted a sharp and rapid decline in the blood pressure of $\mathrm{H}-\mathrm{Ras}^{+} / \mathrm{G} 12 \mathrm{~V}$ and $\mathrm{H}-\mathrm{Ras}^{\mathrm{G} 12 \mathrm{~V} / \mathrm{G} 12 \mathrm{~V}}$ mice. Losartan treatment was also effective in bosentan-treated animals (Figure 6B). These results indicate that the hypertension of these animals is Ang II dependent.

In agreement with these observations, blood vessels from $\mathrm{H}-\operatorname{Ras}^{\mathrm{G} 12 \mathrm{~V} / \mathrm{G} 12 \mathrm{~V}}$ animals were more reactive to Ang II than were their wild-type counterparts (Supplemental Figure 14A). Furthermore, we found that the high Ang II levels in these mice were associated with parallel increases in the expression of components of its biosynthetic and signaling pathways, such as the primary Ang II precursor (angiotensinogen, Agt) and its vasoconstriction-related receptor (Agtr1a; Supplemental Figure $14, \mathrm{~B}$ and $\mathrm{C}$ ). Instead, we observed no statistically significant variations in the transcript levels for enzymes involved in Ang II production, such as renin and Ang II converting enzyme (ACE), or for Ang II receptors involved in vasodilation (Agtr2; Supplemental Figure 14, B and C). Consistent with the absence of pulmonary hypertension described above, the increase in Agtrla transcript levels was detected in aorta and heart but not in pulmonary arteries (Supplemental Figure 14C). Despite the lack of changes in Ace transcript levels, we observed increased levels of ACE activity in hearts from H-Ras ${ }^{\mathrm{G} 12 \mathrm{~V} / \mathrm{G} 12 \mathrm{~V}}$ mice, thus confirming the upregulation of the Ang II biosynthetic pathway in these mutant animals (Supplemental Figure 14D). Taken together, these results indicate that the renin-Ang II system contributes to the hypertensive phenotype of $\mathrm{H}-$ Ras $^{\mathrm{G} 12 \mathrm{~V}}$ mice.

Captopril treatment restores normal blood pressure in H-Ras ${ }^{G 12 V}$ mice. Finally, we evaluated whether the cardiovascular defects observed in $\mathrm{H}-\mathrm{Ras}^{\mathrm{G} 12 \mathrm{~V}}$ mice could be ameliorated by chronic administration of captopril, an inhibitor of the ACE (44). Six-week-old $\mathrm{H}-\mathrm{Ras}^{\mathrm{G} 12 \mathrm{~V} / \mathrm{G} 12 \mathrm{~V}}$ mice were treated with captopril $(250 \mu \mathrm{g} / \mathrm{ml}$ added to the drinking water) for 12 weeks. This treatment effectively halted the increased plasma levels of Ang II, hypertension, remodeling of the aorta media wall, and fibrosis both in the LV and in kidneys (Figure 7, A-F, Figure 8A, and Table 2). In addition, thickening of the aortic valve was also rescued by captopril treatment, although 24 weeks of treatment time were needed (Figure $7, \mathrm{G}-\mathrm{L})$. However, this treatment did not rescue the increased size of the RV and the auricles of H-Ras ${ }^{\mathrm{G} 12 \mathrm{~V}}$ mice (Figure 7, G-L). Instead, captopril treatment induced a $70 \%$ reduction of the LV cardiomyocyte hypertrophy in $\mathrm{H}-$ Ras $^{\mathrm{G} 12 \mathrm{~V}}$ animals (Figure $8 \mathrm{~B}$ ). Consistent with the partial rescue of the LV hypertrophy, we also detected a decrease of about $36 \%$ in the total weight of the hearts of captopril-treated H-Ras ${ }^{\mathrm{G} 12 \mathrm{~V}}$ mice compared with untreated controls (Figure 8C). These observations suggest that the increased number of cardiomyocytes present in these heart chambers is an intrinsic, cell-autonomous effect induced by expression of the $\mathrm{H}-\mathrm{Ras}^{\mathrm{G} 12 \mathrm{~V}}$ oncogene, whereas heart fibrosis, vascular remodeling, renal fibrosis, and most of the concentric LV hypertrophy appear to be indirect consequences of the Ang II-dependent hypertensive condition of mutant $\mathrm{H}-$ Ras $^{\mathrm{G} 12 \mathrm{~V}}$ mice. 


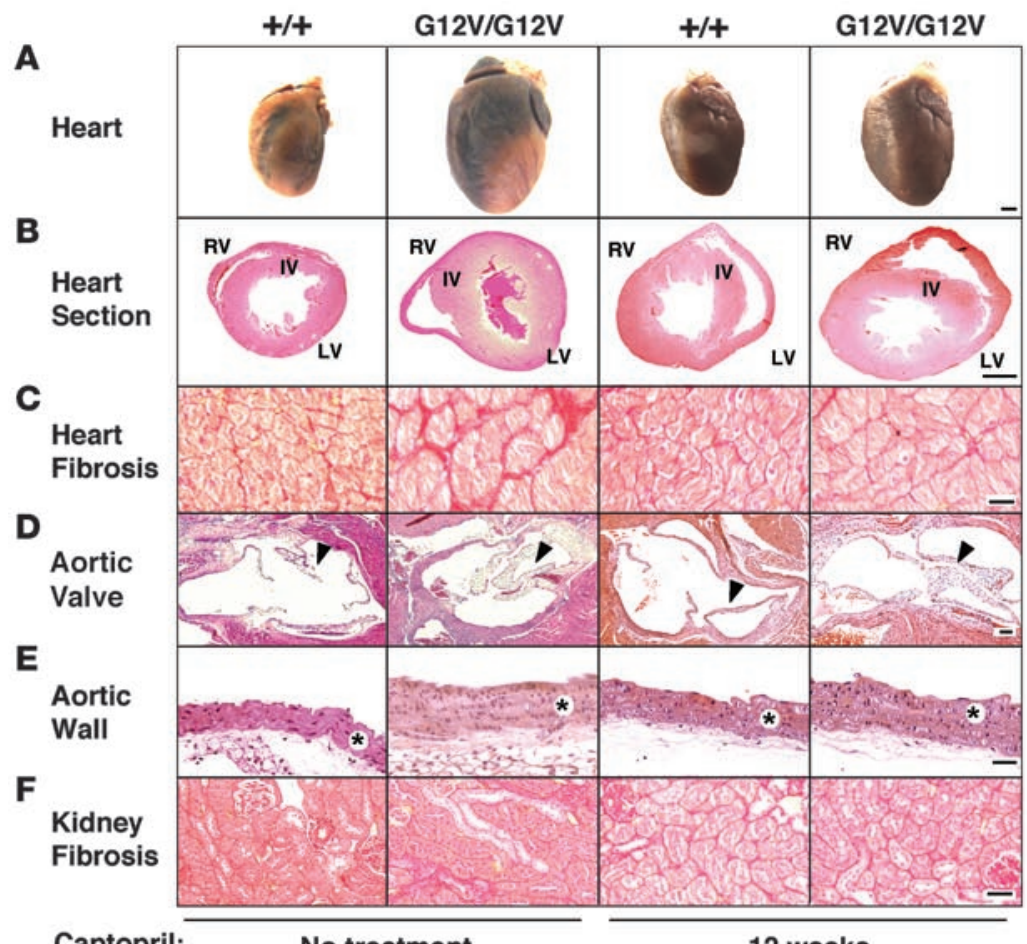

Captopril:

$$
\text { No treatment }
$$

12 weeks

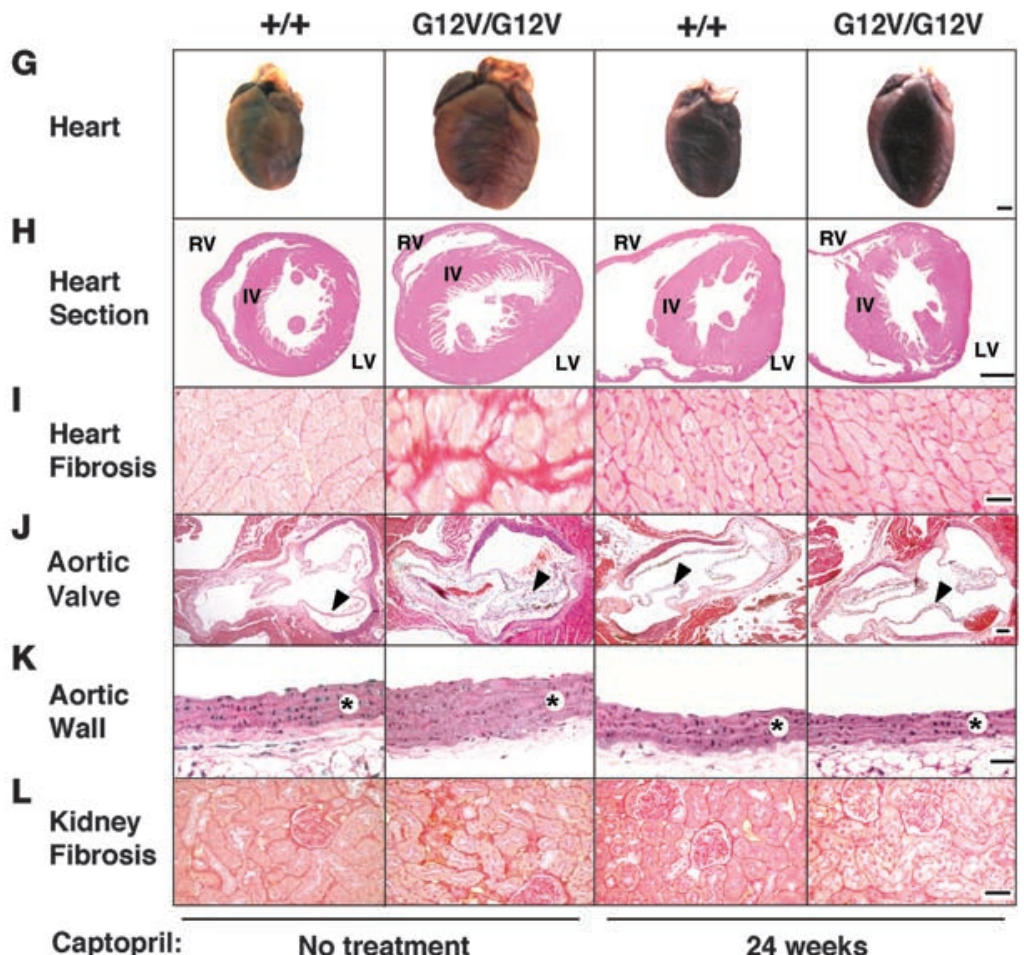

Captopril:

No treatment

24 weeks

\section{Discussion}

CS is a rare developmental defect caused by germline expression of constitutively active, oncogenic alleles of H-RAS. To better understand this syndrome, we have generated a mouse model by introducing one of the mutations known to be responsible for CS within the endogenous mouse $\mathrm{H}$-Ras locus. The resulting mice were viable, even in homozygosity, and closely phenocopied some

\section{Figure 7}

Effect of captopril treatment on heart, aorta, and kidneys of $\mathrm{H}-$ Ras $^{\mathrm{G} 12 \mathrm{~V}}$ mutant mice. $\mathrm{H}-\mathrm{Ras}^{+/+}$and $\mathrm{H}-\mathrm{Ras}^{\mathrm{G} 12 \mathrm{~V} / \mathrm{G} 12 \mathrm{~V}}$ mice were left untreated, or treated with captopril, for $12(\mathbf{A}-\mathbf{F})$ or 24 weeks (G-L). (A and $\mathbf{G})$ Formalin-fixed hearts. (B and $\mathbf{H}) \mathrm{H} \& \mathrm{E}$-stained heart ventricular sections. Interventricular wall, LV, and RV are indicated. (C and I) Fibrosis in the LV, as shown by Sirius red staining. (D and J) H\&E-stained aortic valves (arrowheads). (E and K) H\&E-stained aorta media wall (asterisks). (F and $\mathbf{L}$ ) Kidney fibrosis, as shown by Sirius red staining. Scale bars: $1 \mathrm{~mm}$ (A, B, G, and H); $50 \mu \mathrm{m}$ (D and J); $100 \mu \mathrm{m}(\mathbf{C}, \mathbf{E}, \mathbf{F}, \mathbf{I}, \mathbf{K}$, and L). 
A

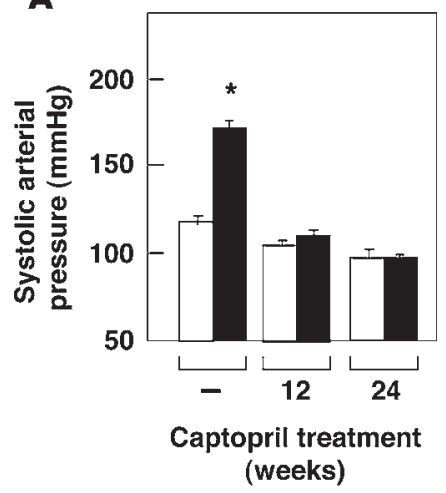

B

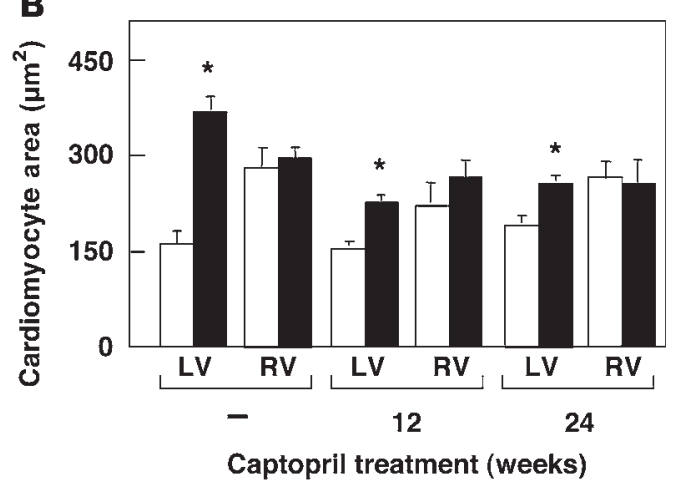

C

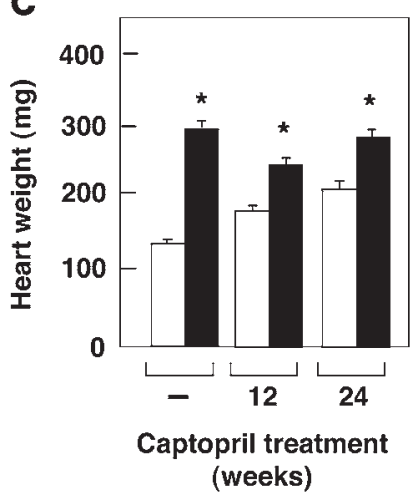

Figure 8

Effect of captopril treatment on cardiovascular parameters of H-RasG12V mutant mice. Systolic arterial pressure (A), LV and RV cardiomyocyte area (B), and total heart weight $(\mathbf{C})$ in $\mathrm{H}-$ Ras $^{+/+}$(white bars) and $\mathrm{H}-\mathrm{Ras}^{\mathrm{G} 12 \mathrm{~V}}$ (black bars) mice that were left untreated or treated with captopril for 12 or 24 weeks. Untreated mice were controls for the 24 -week treatment protocol. ${ }^{*} P<0.01$ versus $\mathrm{H}-\mathrm{Ras}^{+/+}$.

as skin defects and curly hair, can be attributed to interspecies differences. Other defects, such as borderline mental retardation, would be difficult to detect in laboratory mice.

Considering the well-documented involvement of H-Ras oncogenes in tumor development in mice, it is rather surprising that when expressed in the germline, they induce mammary hyperplasia that seldom develops into adenocarcinoma. Moreover, exposure of $\mathrm{H}-$ Ras $^{\mathrm{G} 12 \mathrm{~V}}$ mice to TPA did not result in the development of skin papillomas, indicating that $\mathrm{H}$-Ras oncogenes are not sufficient for tumor initiation in the DMBA/TPA skin carcinogenesis model. Yet they appear to contribute to tumor development, because papillomas of $\mathrm{H}-\mathrm{Ras}^{+/ \mathrm{G} 12 \mathrm{~V}}$ animals displayed mutations in the nontargeted H-Ras allele. Thus, it is possible that the differential levels of tumor susceptibility observed in CS patients and $\mathrm{H}-$ Ras $^{\mathrm{G} 12 \mathrm{~V}}$ mice might be an indirect consequence of the higher levels of carcinogenic exposure that humans endure in a nonprotected environment. Alternatively, the genetic background of the mice used in this study or interspecies differences could explain this disparity. Transfer of the mutated $\mathrm{H}-\mathrm{Ras}^{\mathrm{G} 12 \mathrm{~V}}$ allele to genetic backgrounds more susceptible to tumor development may unveil increased tumor susceptibility in these mutant mice.

A possible explanation for the viability of both mice and humans carrying germline H-Ras oncogenes and the low incidence of tumor development might be the limited activation of the Ras signaling pathways. Even in organs in which we identified defects, such as the kidney and heart, the activation of the Ras/MAPK and PI3K pathways - as determined by the levels of phosphorylated Mek1, Erk1, Erk2, and Akt - is subtle at best. These observations imply either that H-Ras is not a powerful signal transducer in spite of being constitutively bound to GTP or that most cells types have efficient negative regulatory loops that prevent excessive Ras signaling even in the presence of oncogenic H-Ras proteins. Similar results have been previously reported in a mouse model in which an oncogenic H-Ras transgene was overexpressed in cardiomyocytes (45). Yet the defects observed in these mutant mice, as well as in CS patients, suggest that Ras signaling pathways must be altered, albeit at levels that cannot be identified by standard biochemical analysis.

$\mathrm{H}-$ Ras $^{\mathrm{G} 12 \mathrm{~V}}$ mice developed heart cardiomyopathy characterized by general enlargement of all heart chambers, concentric LV hypertrophy, and LV fibrosis. CS patients have rather heterogeneous cardiovascular defects, including cardiovascular malformations, tachyarrhythmias, and cardiac hypertrophy. This latter condition also shows substantial heterogeneinity, because it can develop as a concentric LV, a biventricular hypertrophy, or, in few cases, a dilated cardiomyopathy. The high variability of the heart defects of CS patients compared with the uniform phenotype observed in $\mathrm{H}-\mathrm{Ras}^{\mathrm{G} 12 \mathrm{~V}}$ mice is indicative of additional, individual genetic factors

Table 2

Captopril treatment prevents the hypertensive state of $\mathrm{H}-\mathrm{Ras} \mathrm{G}^{\mathrm{G} 12 \mathrm{~V}}$ mutant mice

$\mathrm{H}-\mathrm{RaS}^{+++}$

\section{Parameter}

Systolic AP, conscious ( $\mathrm{mmHg}$ )

Mean AP, unconscious ( $\mathrm{mmHg}$ )

Aorta media wall thickness $(\mu \mathrm{m})$

Ang II (pg/ml plasma)

Norepinephrine (nmol/ml plasma)

Untreated
$\begin{array}{r}111.6 \pm 3.5 \\ 53.5 \pm 0.5 \\ 42.1 \pm 6.1 \\ 21.9 \pm 1.9 \\ 1.1 \pm 0.1\end{array}$

Captopril $(\% \text { change })^{\mathrm{A}}$

Values in parentheses denote percent change compared with the untreated group. Differences between captopril-treated H-Ras ${ }^{+/+}$and $\mathrm{H}-\mathrm{Ras}_{\mathrm{G} 12 \mathrm{~V} / \mathrm{G} 12 \mathrm{~V}}$ mice were not significant. AP, arterial pressure. ${ }^{A}$ Captopril treatment in $\mathrm{H}-$ Ras $^{+/+}$mice induced a significant decrease in Ang II as well as in RV cardiomyocyte size $(-18 \%$; not shown); all other parameters measured remained constant. 
that cooperate with $\mathrm{H}-\mathrm{Ras}^{\mathrm{G}}{ }^{\mathrm{I} 2 \mathrm{~V}}$ signaling to induce multiple heart dysfunctions. Backcrossing H-Ras ${ }^{\mathrm{G} 12 \mathrm{~V}}$ mice to other genetic backgrounds should allow us to verify this possibility, and if so, to identify those loci that contribute to the heterogeneous clinical manifestations of heart malfunctions in CS patients.

Analysis of the H-Ras ${ }^{\mathrm{G} 12 \mathrm{~V}}$ hearts revealed a consistent thickening of the aortic valve without alterations in the pulmonary or atrioventricular valves. Such specificity is not observed in mouse models for other NCFC syndromes, such as NF1 and NS (36-38). Moreover, it has been reported that some CS patients develop pulmonic but not aortic stenosis (34). In NF1 and NS mice, valvular defects arise by alterations in endothelial and neural crest cells during embryogenesis. The defect in the aortic valve of $\mathrm{H}-\mathrm{Ras}^{\mathrm{G} 12 \mathrm{~V}}$ mice does not appear to occur during embryonic development, because there were no significant abnormalities in embryonic hearts (our unpublished observations). Moreover, the aortic valve defects could be eliminated during adulthood by treating $\mathrm{H}-\mathrm{Ras}^{\mathrm{G} 12 \mathrm{~V}}$ mice with captopril. Taken together, these results indicate that the aortic valve malformations found in $\mathrm{H}-\mathrm{Ras}^{\mathrm{G} 12 \mathrm{~V}}$ mice are not caused by an intrinsic, cell-autonomous effect of $\mathrm{H}-\mathrm{Ras}^{\mathrm{G}}{ }^{\mathrm{G} 2 \mathrm{~V}}$ signaling, but rather are a consequence of other collateral dysfunctions. It should be noted that systemic high levels of Ang II did not usually lead to aortic valve thickening, indicating that this defect may result from the synergistic action of Ang II-induced hypertension and abnormal H-Ras ${ }^{\mathrm{G} 12 \mathrm{~V}}$ signaling.

The cardiovascular phenotype of H-Ras ${ }^{\mathrm{G} 12 \mathrm{~V}}$ mice can result from activation of the Ang II pathway, activation of H-Ras, and/or synergistic crosstalk between the Ang II and H-Ras ${ }^{\mathrm{G} 12 \mathrm{~V}}$ pathways. Studies with $\operatorname{Vav}^{-/-}$mice revealed defects that overlapped with those described here, in spite of the fact that $\operatorname{Vav~}^{-/-}$animals did not express constitutively activated H-Ras proteins (V. Sauzeau and X.R. Bustelo, unpublished observations). Vav $3^{-/-}$mice have LV hypertrophy and fibrosis, vascular remodeling, and renal fibrosis (46). In addition, they display upregulation of the Ang II biosynthetic route, elevated levels of Agtr1a but not of Agtr2 mRNAs, and enhanced contractile reactions of their blood vessels to Ang II (ref. 46 and our unpublished observations). However, Vav $3^{-/-}$mice, unlike $\mathrm{H}-\operatorname{Ras}^{\mathrm{G} 12 \mathrm{~V}}$ animals, do not show alterations in the size of the other heart chambers or in the structure of aortic valves (ref. 46 and our unpublished observations). Captopril efficiently halted the development of all renocardiovascular defects of $\mathrm{Vav}^{-/-}$mice, including the LV hypertrophy (46), a defect only partially rescued in $\mathrm{H}-\mathrm{Ras}^{\mathrm{G} 12 \mathrm{~V}}$ mice. These results suggest that the cardiovascular defects present in $\mathrm{H}-\mathrm{Ras}^{\mathrm{G} 12 \mathrm{~V}}$ mutant mice originate from different signaling dysfunctions. Thus, heart hyperplasia might be caused exclusively by abnormal H-Ras signaling. Other defects, such as vascular remodeling, heart fibrosis, kidney fibrosis, and increased levels of Agtr1a mRNA, might be due to Ang II-dependent pathways. Still other defects, such as LV hypertrophy, could result from the combined effect of H-Ras ${ }^{\mathrm{G} 12 \mathrm{~V}}$ - and Ang II-dependent signaling routes working in parallel. Finally, a fourth subset of defects, including aortic valve enlargement, may originate from the synergistic interaction between these 2 pathways.

The identification of Ang II-dependent systemic hypertension in $\mathrm{H}-\mathrm{Ras}^{\mathrm{G} 12 \mathrm{~V}}$ mice could be of clinical interest. To date, hypertension in CS patients has been described in few cases (6). However, it is unclear whether more CS patients develop a hypertensive state as they age. It is possible that this condition may have gone undetected, because most patients with CS do not undergo periodic medical examinations after reaching adulthood. In H-Ras ${ }^{\mathrm{G} 12 \mathrm{~V}}$ mice, we have shown that systemic, Ang II-dependent hypertension induced extensive vascular remodeling, moderate increases in epinephrine, and fibrosis in the LV and in the kidneys. Treatment of these animals with antihypertensive drugs rescued the tissue fibrosis and the engrossment of aortic valves. It also partially rescued the hypertrophy of LV cardiomyocytes. Thus, a substantial percentage of heart defects found in $\mathrm{H}-\mathrm{Ras}^{\mathrm{G} 12 \mathrm{~V}}$ mice are the indirect result of their hypertensive state. In fact, only the overall increase in the size of the auricles and RV appeared to be a cell-autonomous effect unrelated to hypertension. Based on these observations, it will be important to determine whether hypertension occurs in CS patients. If so, it is likely that they could benefit from classical antihypertensive therapies.

Ang II-dependent hypertension can be induced by a plethora of different dysfunctions, including renal defects, alterations in the SNS or in brain cardiorespiratory centers, certain tumor types (i.e., pheochromocytoma), increased vascular resistance, and/or other physiological problems. Our analyses have indicated that the hypertension of $\mathrm{H}-\mathrm{Ras}^{\mathrm{G} 12 \mathrm{~V}}$ mice cannot be attributed to alterations in kidney physiology, adrenal gland-related hormones, cardiorespiratory brainstem centers or SNS control. Whether the $\mathrm{H}-\mathrm{Ras}^{\mathrm{G} 12 \mathrm{~V}}$ protein promotes hypertension through alterations in other brain centers, vascular smooth muscle cells, or endothelial cells that ultimately result in the activation of the renin-Ang II system remains to be determined. Further work will be required to identify the signaling route and cell types involved in the development of hypertension and its associated pathologies.

The availability of an animal model for CS, as well as for other NCFC syndromes, may unveil defects undetected to date and help to develop potentially useful therapeutic strategies. For example, the H-Ras oncoprotein, unlike the other members of the Ras superfamily of proteins, is thought to be absolutely dependent on posttranslational farnesylation for biological activity (47). Therefore, it would be important to determine whether inhibiting H-Ras farnesylation by either genetic (by crossing H-Ras ${ }^{\mathrm{G} 12 \mathrm{~V}}$ animals with FTaselox/lox mice) or pharmacological (by treating with FTase inhibitors) means could eliminate, or at least ameliorate, the CS-like defects observed in $\mathrm{H}-\mathrm{Ras}^{\mathrm{G} 12 \mathrm{~V}}$ mice $(48,49)$. Likewise, $\mathrm{H}-\mathrm{Ras}^{\mathrm{G} 12 \mathrm{~V}}$ mice could be used to test whether inhibitors of the Raf/Mek/Erk pathway or the PI3K/ Akt route could have therapeutic properties for CS patients. The results of our present study should have a significant impact on our understanding and future treatment of CS.

\section{Methods}

Generation of H-Ras mutant mice. Animal use was in accordance with the animal care standards established by the European Union. All experiments were reviewed and approved by the Animal Care Committee of the Institute of Health Carlos III and the University of Salamanca. To target the H-Ras locus, we generated a $3^{\prime} \mathrm{H}$-Ras targeting vector by subcloning a $4.5-\mathrm{kbp}$ HindIII DNA fragment from a 129Sv/J genomic library into pBlueScript SKII. This DNA fragment contains most H-Ras coding sequences and $2.5 \mathrm{kbp}$ of the $3^{\prime}$ untranslated region. Next, an IRES- $\beta$-geo cassette (50) was inserted into an XbaI site generated by site-directed mutagenesis $263 \mathrm{bp}$ downstream from the TGA translational stop codon and 149 bp upstream from the putative polyadenylation site (Supplemental Figure 1A). This targeting vector was linearized with SalI and electroporated into R1 ES cells (51) as previously described (52). Thirty of 54 clones were identified as $\mathrm{H}-\mathrm{Ras}^{+} / \mathrm{geo}$ recombinants by Southern blot analysis (Supplemental Figure $1 \mathrm{~B})$. To generate the $5^{\prime}$ targeting vector, we first subcloned a $4.7-\mathrm{kbp}$ KpnI-SpeI DNA fragment from a $129 \mathrm{~Sv} / \mathrm{J}$ genomic library into the cloning 
plasmid pMECA (53). This DNA fragment, which contains 3,052 bp of the $5^{\prime}$ untranslated region, exons $0-3$, and the first 24 bp of exon 4 , was used to insert an LSL cassette (loxP-PGK-Hyg-STOP-loxP; ref. 54) into a NotI site generated by site-directed mutagenesis $147 \mathrm{bp}$ upstream of exon 1 (Supplemental Figure 1C). In addition, we mutagenized the middle nucleotide of codon 12 (GGA $\rightarrow$ GTA; Supplemental Figure 1C). This targeting vector was linearized with Eam1105I and electroporated into H-Ras ${ }^{+}$geo ES cells as described above. Four of 1,152 clones were identified as homologous recombinants by Southern blot analysis (Supplemental Figure 1D). Of these clones, 2 were negative for $\beta$-gal activity, which suggested that the $5^{\prime}$ recombination event occurs in the H-Rasgeo allele. These putative H-Ras ${ }^{+/ L S L G 12 \mathrm{~V}}$ clones were transfected with a plasmid encoding a bacteriophage Cre recombinase to ensure that excision of the LSL cassette restored expression of the $\beta$-geo protein. ES clones carrying the $\mathrm{H}$-Rasgeo and $\mathrm{H}$-Ras ${ }^{\mathrm{LSLG} 12 \mathrm{~V}}$ alleles were used to generate chimeric mice by microinjection into C57BL/6J blastocysts. These mice were crossed to $\mathrm{C} 57 \mathrm{BL} / 6 \mathrm{~J}$ females to obtain germline transmission of the targeted alleles. H-Ras ${ }^{+/ L S L G 12 V}$ mice were crossed with EIIaCre transgenics that express Cre at the zygote stage (55) to allow efficient cleavage of the LSL cassette in the germline (Supplemental Figure 1E). Mice carrying the $\mathrm{H}-\mathrm{Ras}^{\mathrm{G} 12 \mathrm{~V}}$ allele were crossed to $\mathrm{C} 57 \mathrm{BL} / 6 \mathrm{~J}$ mice to eliminate the EIIaCre transgene and subsequently among themselves to generate the homozygous strain. Mice were maintained in a mixed 129Sv/J $\times$ C57BL/6J background and housed in a barrier facility according to animal care standards established by the European Union. Routine genotyping of $\mathrm{H}$-Ras ${ }^{+}, \mathrm{H}-$ Ras $^{\text {geo }}, \mathrm{H}-$ Ras $^{\mathrm{LSLG} 12 \mathrm{~V}}$, and $\mathrm{H}-$ Ras $^{\mathrm{G} 12 \mathrm{~V}}$ alleles was carried out by PCR amplification (see Supplemental Methods).

Western blot analysis. To compare the expression levels of endogenous wildtype H-Ras and mutant $\mathrm{H}-\mathrm{Ras}^{\mathrm{G} 12 \mathrm{~V}}$ proteins based on their different electrophoretic mobilities (56), $200 \mu \mathrm{g}$ protein extract from various tissues was separated in $15 \%$ SDS-PAGE, transferred to nitrocellulose filters, and incubated with anti-H-Ras mouse monoclonal antibody (Ras, clone 18; BD Biosciences). The primary antibody was detected with a polyclonal goat anti-mouse horseradish peroxidase-linked secondary antibody and visualized with an enhanced chemiluminescent system (ECL Plus; Amersham Biosciences). To determine the levels of expression of H-Ras and its downstream effectors, $40 \mu \mathrm{g}$ protein extract obtained from various tissues was resolved by SDS-PAGE, transferred to a nitrocellulose membrane, and blotted with the anti-H-Ras mouse monoclonal antibody or with polyclonal antibodies elicited against Erk1/2 (C-16; Santa Cruz Biotechnology Inc.), phosphorylated Erk1/2 (phosphoresidues Thr202 and Tyr204; Cell Signaling Technology), Mek1 (C-18; Santa Cruz Biotechnology Inc.), phosphorylated Mek1 (phosphoresidues Ser217 and Ser221; Cell Signaling Technology), Akt (Cell Signaling Technology), phosphorylated Akt (phosphoresidue Ser473; Cell Signaling Technology), and GAPDH (Sigma-Aldrich) for loading control. Primary antibodies were detected with corresponding goat secondary antibodies against mouse or rabbit IgGs (Alexa Fluor 680; Invitrogen) and visualized with a LI-COR system (Odyssey). To measure active GTP-bound H-Ras protein, $1 \mathrm{mg}$ (brain) or $3 \mathrm{mg}$ (embryos) of protein extracts were processed with a Ras activation assay kit (Cell Biolabs) according to the manufacturer's instructions. Pulled-down H-Ras protein was detected by Western blot analysis using the monoclonal H-Ras antibody described above.

Histopathology and immunohistochemistry. Embryos or tissues were processed for immunohistochemistry analysis, whole-mount studies, and $\beta$-gal expression as described in Supplemental Methods.

Skin carcinogenesis. Ten-day-old mice were treated with a single $25-\mu \mathrm{g}$ dose of DMBA (Sigma-Aldrich) followed 1 week later by exposure to TPA (Sigma-Aldrich) for 24 weeks (12.5 $\mu \mathrm{g}$ twice a week). To identify the presence of H-Ras mutations, genomic DNA encompassing H-Ras-coding exons 1 and 2 was amplified by PCR from papilloma DNAs as described in Supplemental Methods.
CT. The CT acquisition was performed with an eXplore Vista PET CT (GE Healthcare) using an amperage of $200 \mu \mathrm{A}$ and a voltage of $35 \mathrm{kV}$. Twomonth-old mice were anesthetized with ketamine $(75 \mathrm{mg} / \mathrm{kg}$ body weight; Imalgene ${ }^{500}$; Merial) and xylazine ( $1 \mathrm{mg} / \mathrm{kg}$ body weight, Ronpum; Bayer) during acquisition. To assess the morphological differences in newborn mice, we collected a set of 12 2-dimensional landmarks in the midsagittal plane of the skull (Supplemental Figure 8). Landmark configurations were aligned by translation and rotation in a generalized Procrustes analysis, a least-squares fitting of all 2-dimensional configurations to the average (57). Differences between groups in the spatial position of these landmarks were determined by Hotelling $T^{2}$ test of each pair of $x y$ coordinates.

Hemodynamic studies. Four-month-old mice were anesthetized with sodium phentobarbital ( $40 \mathrm{mg} / \mathrm{kg}$ body weight; Sigma-Aldrich). Arterial pressures were recorded by catheterization of the right carotid artery with a pressure probe connected to a digital data recorder (MacLab/4e; ADInstruments), as previously described (58). Recordings were subsequently analyzed with the Chart version 3.4 software (ADInstruments). Blood pressures and heart rates were recorded after a 20-minute stabilization period after catheterization. Blood pressure and heart rate were also recorded in conscious mice with an automated multichannel system using the tail-cuff method and a photoelectric sensor (Niprem 546; Cibertec SA). Plasma levels of Ang II and ET1 were determined by ELISA as described previously (46). Creatinine concentrations in urine and plasma were determined by a modification of the Jaffe reaction method (59). Urinary electrolyte concentration was measured using a Hitachi 917 autoanalyzer. Total collagen present in tissues was quantified by spectrophotometric analysis of hydroxyproline levels. For in situ visualization of fibrosis, paraffin-embedded tissue sections were stained with Sirius red (Fluka). For pharmacologic studies, losartan (DuPont) and bosentan (Sigma-Aldrich) were injected in the left jugular vein of animals ( $10 \mathrm{mg} / \mathrm{kg}$ body weight), and blood pressures were measured in real time as described above. To inhibit the Ang II system, 6-week-old mice were treated with captopril (Sigma-Aldrich) added to the drinking water $(250 \mu \mathrm{g} / \mathrm{ml})$ for the indicated periods of time.

Statistics. In CT studies, differences between groups were determined by Hotelling $T^{2}$ test. In cardiovascular studies, results were expressed as mean \pm SEM. $n$ was also indicated. H-Ras ${ }^{+/ G 12 \mathrm{~V}}$ and H-Ras ${ }^{\mathrm{G} 12 \mathrm{~V} / \mathrm{G} 12 \mathrm{~V}}$ mice were compared with $\mathrm{H}-\mathrm{Ras}^{+/+}$mice using 1 -tailed Student's $t$ test. A $P$ value less than 0.05 was considered significant.

\section{Acknowledgments}

We thank L. Barata, M. Lamparero, M.J. Montero, M. San Román, and R. Villar for excellent technical assistance. We also value the support provided by the Transgenic, Comparative Pathology, and Imaging Units of the Centro Nacional de Investigaciones Oncológicas and the Anatomopathology Unit of the Centro de Investigación del Cáncer. We thank E. Santos for the DNA clone (pLM91) containing the H-Ras locus; H. Westphal for the EIIaCre transgenic mice; M. Desco, F. Mulero, M.L. Soto, and S. Reig for the CT images; and P. Dubus for critical reading of the manuscript. This work was supported by grants from the Spanish Ministry of Education and Science to M. Barbacid (SAF2003-05172 and SAF2004-20477-E) and X.R. Bustelo (SAF2006-01789); from the VI Framework Programme of the European Union to M. Barbacid (LSHC-CT-2004-503438, LSHG-CT-2007-037665, and LSHGCT-2006-037188); from the National Cancer Institute, NIH, to X.R. Bustelo (5R01-CA73735-10); from the Fondo de Investigación Sanitaria to C. Guerra (PI042124); from the Red Temática de Investigación Cooperativa en Cáncer, Instituto de Salud Carlos III, to X.R. Bustelo (RD06/0020/0001); from the Autonomous Community of Madrid to M. Barbacid (GR/SAL/0587/2004) and 
C. Guerra (GR/SAL/0349/2004); from the Autonomous Government of Castilla-León to X.R. Bustelo (SA053A05); and from the Fundación de la Mutua Madrileña de Automóviles to M. Barbacid. All Spanish funding to X.R. Bustelo is cosponsored by the European Union FEDER program. A.J. Schuhmacher is supported by a FPU fellowship from the Spanish Ministerio de Educación y Ciencia (MEC). V. Sauzeau is partially supported by a Juan de la Cierva postdoctoral contract from the MEC.

Received for publication November 1, 2007, and accepted in revised form March 26, 2008.

1. Costello, J.M. 1971. A new syndrome. N. Z. Med. J. 74:397.

2. Hennekam, R.C. 2003. Costello syndrome: an overview. Am. J. Med. Genet. C. Semin. Med. Genet. 117:42-48.

3. Schubbert, S., Shannon, K., and Bollag, G. 2007. Hyperactive Ras in developmental disorders and cancer. Nat. Rev. Cancer. 7:295-308.

4. Rauen, K.A. 2007. HRAS and the Costello syndrome. Clin. Genet. 71:101-108.

5. Aoki, Y., et al. 2005. Germline mutations in HRAS proto-oncogene cause Costello syndrome. Nat. Genet. 37:1038-1040.

6. Estep, A.L., Tidyman, W.E., Teitell, M.A., Cotter, P.D., and Rauen, K.A. 2006. HRAS mutations in Costello syndrome: detection of constitutional activating mutations in codon 12 and 13 and loss of wild-type allele in malignancy. Am. J. Med. Genet. A. 140:8-16.

7. Gripp, K.W., et al. 2006. HRAS mutation analysis in Costello syndrome: genotype and phenotype correlation. Am. J. Med. Genet. A. 140:1-7.

8. Kerr, B., et al. 2006. Genotype-phenotype correlation in Costello syndrome: HRAS mutation analysis in 43 cases. J. Med. Genet. 43:401-405.

9. Carta, C., et al. 2006. Germline missense mutations affecting KRAS Isoform $B$ are associated with a severe Noonan syndrome phenotype. Am. J. Hum. Genet. 79:129-135.

10. Bertola, D.R., et al. 2007. Further evidence of genetic heterogeneity in Costello syndrome: involvement of the KRAS gene. J. Hum. Genet. 52:521-526.

11. Zenker, M., et al. 2007. Expansion of the genotypic and phenotypic spectrum in patients with KRAS germline mutations. J. Med. Genet. 44:131-135.

12. Sovik, O., et al. 2007. De novo HRAS and KRAS mutations in two siblings with short stature and neuro-cardio-facio-cutaneous features. J. Med. Genet. 44:e84.

13. Tartaglia, M., et al. 2001. Mutations in PTPN11, encoding the protein tyrosine phosphatase SHP-2, cause Noonan syndrome. Nat. Genet. 29:465-468.

14. Roberts, A.E., et al. 2007. Germline gain-of-function mutations in SOS1 cause Noonan syndrome. Nat. Genet. 39:70-74.

15. Tartaglia,M., etal.2007. Gain-of-functionSOS1 mutations cause a distinctive form of Noonan syndrome. Nat. Genet. 39:75-79.

16. Schubbert, S., et al. 2006. Germline KRAS mutations cause Noonan syndrome. Nat. Genet. 38:331-336.

17. Pandit, B., et al. 2007. Gain-of-function RAF1 mutations cause Noonan and LEOPARD syndromes with hypertrophic cardiomyopathy. Nat. Genet. 39:1007-1012.

18. Razzaque, M.A., et al. 2007. Germline gain-of-function mutations in RAF1 cause Noonan syndrome. Nat. Genet. 39:1013-1017.

19. Zenker, M., et al. 2007. SOS1 is the second most common Noonan gene but plays no major role in cardio-facio-cutaneous syndrome. J. Med. Genet. 44:651-656

20. Rodriguez-Viciana, P., et al. 2006. Germline mutations in genes within the MAPK pathway

Address correspondence to: Xosé R. Bustelo, Centro de Investigación del Cáncer, CSIC/University of Salamanca, Campus Miguel de Unamuno, E-37007 Salamanca, Spain. Phone: 34-923294802; Fax: 34-923294743; E-mail: xbustelo@usal.es. Or to: Mariano Barbacid, Molecular Oncology Programme, Centro Nacional de Investigaciones Oncológicas, C/Melchor Fernández Almagro, 3, E-28029 Madrid, Spain. Phone: 34-912246938; Fax: 34-917328010; E-mail: mbarbacid@cnio.es.

Alberto J. Schuhmacher, Carmen Guerra, and Vincent Sauzeau contributed equally to this work.

cause cardio-facio-cutaneous syndrome. Science. 311:1287-1290.

21. Niihori, T., et al. 2006. Germline KRAS and BRAF mutations in cardio-facio-cutaneous syndrome. Nat. Genet. 38:294-296.

22. Digilio, M.C., et al. 2002. Grouping of multiple-lentigines/LEOPARD and Noonan syndromes on the PTPN11 gene. Am.J. Hum. Genet. 71:389-394.

23. Legius, E., et al. 2002. PTPN11 mutations in LEOPARD syndrome. J. Med. Genet. 39:571-574.

24. Viskochil, D., et al. 1990. Deletions and a translocation interrupt a cloned gene at the neurofibromatosis type 1 locus. Cell. 62:187-192.

25. Cawthon, R.M., et al. 1990. A major segment of the neurofibromatosis type 1 gene: cDNA sequence, genomic structure, and point mutations. Cell. 62:193-201.

26. Cichowski, K., and Jacks, T. 2001. NF1 tumor suppressor gene function: narrowing the GAP. Cell. 104:593-604.

27. Gripp, K.W., et al. 2008. Costello syndrome associated with novel germline HRAS mutations: An attenuated phenotype? Am. J. Med. Genet. A. 146:683-690

28. Guerra, C., et al. 2003. Tumor induction by an endogenous K-ras oncogene is highly dependent on cellular context. Cancer Cell. 4:111-120.

29. Leon, J., Guerrero, I., and Pellicer, A. 1987. Differential expression of the ras gene family in mice. Mol. Cell Biol. 7:1535-1540.

30. Gripp, K.W. 2005. Tumor predisposition in Costello syndrome. Am. J. Med. Genet. C. Semin. Med. Genet. 137:72-77.

31. Balmain, A., and Pragnell, I.B. 1983. Mouse skin carcinomas induced in vivo by chemical carcinogens have a transforming Harvey-ras oncogene. Nature. 303:72-74.

32. Brown, K., Buchmann, A., and Balmain, A. 1990. Carcinogen-induced mutations in the mouse c-Ha-ras gene provide evidence of multiple pathways for tumor progression. Proc. Natl. Acad. Sci.U. S. A. 87:538-542.

33. Quintanilla, M., Brown, K., Ramsden, M., and Balmain, A. 1986. Carcinogen-specific mutation and amplification of Ha-ras during mouse skin carcinogenesis. Nature. 322:78-80.

34. Lin, A.E., et al. 2002. Further delineation of cardiac abnormalities in Costello syndrome. Am. J. Med. Genet. 111:115-129.

35. Hinek, A., et al. 2005. Myocardial storage of chondroitin sulfate-containing moieties in Costello syndrome patients with severe hypertrophic cardiomyopathy. Am. J. Med. Genet. A. 133:1-12.

36. Chen, B., et al. 2000. Mice mutant for Egfr and Shp2 have defective cardiac semilunar valvulogenesis. Nat. Genet. 24:296-299.

37. Gitler, A.D., et al. 2003. Nf1 has an essential role in endothelial cells. Nat. Genet. 33:75-79.

38. Araki, T., et al. 2004. Mouse model of Noonan syndrome reveals cell type- and gene dosage-dependent effects of Ptpn11 mutation. Nat. Med. 10:849-857.

39. Lifton, R.P., Gharavi, A.G., and Geller, D.S. 2001. Molecular mechanisms of human hypertension.
Cell. 104:545-556.

40. DiBona, G.F., and Sawin, L.L. 2004. Effect of renal denervation on dynamic autoregulation of renal blood flow. Am. J. Physiol. Renal. Physiol. 286:F1209-F1218.

41. Guyenet, P.G. 2006. The sympathetic control of blood pressure. Nat. Rev. Neurosci. 7:335-346.

42. Takahashi, N., and Smithies, O. 1999. Gene targeting approaches to analyzing hypertension. J. Am. Soc. Nephrol. 10:1598-1605.

43. Remuzzi, G., Perico, N., and Benigni, A. 2002. New therapeutics that antagonize endothelin: promises and frustrations. Nat. Rev. Drug Discov. 1:986-1001.

44. Momma, K. 2006. ACE inhibitors in pediatric patients with heart failure. Paediatr. Drugs. 8:55-69.

45. Zheng, M., et al. 2004. Sarcoplasmic reticulum calcium defect in Ras-induced hypertrophic cardiomyopathy heart. Am. J. Physiol. Heart Circ. Physiol. 286:H424-H433.

46. Sauzeau, V., et al. 2006. Vav3 proto-oncogene deficiency leads to sympathetic hyperactivity and cardiovascular dysfunction. Nat. Med. 12:841-845.

47. Zhang, F.L., and Casey, P.J. 1996. Protein prenylation: molecular mechanisms and functional consequences. Annu. Rev. Biochem. 65:241-269.

48. Mijimolle, N., et al. 2005. Protein farnesyltransferase in embryogenesis, adult homeostasis, and tumor development. Cancer Cell. 7:313-324.

49. Sebti, S.M. 2005. Protein farnesylation: Implications for normal physiology, malignant transformation, and cancer therapy. Cancer Cell. 7:297-300.

50. Mountford, P., et al. 1994. Dicistronic targeting constructs: reporters and modifiers of mammalian gene expression. Proc. Natl. Acad. Sci. U. S. A. 91:4303-4307.

51. Nagy, A., et al. 1993. Derivation of completely cell culture-derived mice from early-passage embryonic stem cells. Proc. Natl. Acad. Sci. U. S. A. 90:8424-8428.

52. Ortega, S., et al. 2003. Cyclin-dependent kinase 2 is essential for meiosis but not for mitotic cell division in mice. Nat. Genet. 35:25-31.

53. Thomson, J.M., and Parrott, W.A. 1998. pMECA: a cloning plasmid with 44 unique restriction sites that allows selection of recombinants based on colony size. Biotechniques. 24:922-928.

54. Lakso, M., et al. 1992. Targeted oncogene activation by site-specific recombination in transgenic mice. Proc. Natl. Acad. Sci. U. S. A. 89:6232-6236.

55. Lakso, M., et al. 1996. Efficient in vivo manipulation of mouse genomic sequences at the zygote stage. Proc. Natl. Acad. Sci. U. S. A. 93:5860-5865.

56. Joyce, A.D., et al. 1989. Detection of altered H-ras proteins in human tumors using western blot analysis. Lab. Invest. 61:212-218.

57. Rohlf, F.J., and Slice, D. 1990. Extensions of the procrustes method for the optimal superimposition of landmarks. Syst. Zool. 39:40-59.

58. Jerkic, M., et al. 2004. Endoglin regulates nitric oxidedependent vasodilatation. FASEB J. 18:609-611.

59. Valdivielso, J.M., et al. 2001. Renal ischemia in the rat stimulates glomerular nitric oxide synthesis. Am. J. Physiol. Regul. Integr. Comp. Physiol. 280:R771-R779. 